\title{
Econometric Analysis of the Effect of External Debt on the Economic Growth of Nigeria
}

\author{
Dr. Chris AC-Ogbonna ${ }^{1}$ and Napoleon David Okosu ${ }^{2}$ \\ ${ }^{1}$ Department of Economics \\ Veritas University Abuja \\ ${ }^{2}$ Financial Policy and Regulation Department \\ Central Bank of Nigeria, Abuja
}

Nigeria

\begin{abstract}
This study looks at the analysis of the effect of external debt on the Economic Growth of Nigeria from 1980 to 2017 with secondary data sourced from Central Bank of Nigeria and Debt Management Office statistical/annual bulletins of various years. The Autoregressive Distributed Lag (ARDL) Method is employed in the estimation of the multivariate regression model. In the data analysis, External Debt (EXDT), External Debt service (EXDS), and Exchange Rate (EXCHR) were used as independent variables against the dependent variable of Real Gross Domestic Product (RGDP) which is used as proxy for economic growth. The result of the study showed that external debt has an insignificant and positive linear relationship with the level of economic growth in Nigeria, an increase in external debt by a unit will increase the level of economic growth by 0.091 units. This is an indication that external debt has the potentials of increasing the level of economic progress in Nigeria. External debt service has no significant but positive impact on the level of economic growth in Nigeria. This is not surprising since income from investment of external debts in self-liquidating projects is used in servicing the debts. Exchange rate has no significant and positive effect on the level of economic growth in Nigeria. Based on the findings, the study therefore recommends that economic managers in the country should apply foreign loans only on beneficial capital investments capable of liquidating itself rather than spend it on recurrent expenditure. This will reduce the crowding out effect of debt and debt overhang on the Nigerian economy. Only external loans with favourable terms and conditions should be sort for by the country to avoid excessive debt burden on the economy. Only low cost foreign loans should be sort for after a rigorous evaluation not on exigency to reduce the cost of the debt. Measures that will stabilize exchange rates in the country should be put in place to check its adverse effects on the economy.
\end{abstract}

Key Words: Econometric Analysis, Economic Growth, External Debt.

\section{BACKGROUND TO THE STUDY}

External debt is one of the sources of financing capital formation in any economy, it can stimulate the economy and engender economic growth if effectively and efficiently used. The first external debt in Nigeria was obtained in 1958 when the Nigeria government borrowed US\$28 million from the World Bank to finance railway constructions. After the oil boom from 1971-1977, external loans were taken to maintain the tempo of economic growth and development already gingered by the oil boom. According to Debt Management Office, the need for the first jumbo loan arose from the depletion of our foreign resources and shortage of foreign exchange required for capital goods imports. The foreign exchange shortage was due to the drastic fall in the price and demand for oil in the world market since oil is the country's major foreign exchange earner; there was therefore, a decrease in income for the Government. It was then reasoned that the borrowed funds when invested would build greater incomes for the government; and the benefits would help to offset the loans and its interest payment. Consequently, the jumbo loan of $\$ 1$ billion was borrowed from the International Capital Market in 1978 increasing total external debt to \$2.2 billion [1]. Thereafter, more external borrowing was undertaken from Paris Club, London Club of Creditors, bilateral and multilateral agencies. Sooner than expected, Nigeria began to face debt crises, which lingered till date.

As opined by Soludo, C.C nations countries borrow for two broad categories; macroeconomic reasons to either finance higher investment or higher consumption and to circumvent hard budget constraint. This implies that a nation borrow to boost economic growth and alleviate poverty [2]. He stated further that when debt reaches a certain level, it will have a negative impact on the 
economy, then debt servicing obligations becomes a massive burden and nations find themselves on the wrong side of the debtlaffer curve, with debt crowding out investment and growth. [2]

The most indebted countries of the developing world are trapped on a debt treadmill as they are forced to take new loans to pay old ones or risk default and potential economic collapse. Most African countries, paid more in debt and debt servicing between 1990 and 1993 than they spent on basic societal needs like education and health care. Still they watched their debt load double. As the Nigerian government reels under financial pressure to generate foreign currency to pay the rising debt, poverty and environmental devastation increase. The pressure on government to deliver basic amenities was increasing and government went on to borrow. Although the debt overhang models do not analyse the effects of debt on growth explicitly, the implication still remains that large debt stocks deplete growth by partly reducing investment with a resultant negative effect on poverty. But the incentive effects associated with debt stocks tend to reduce the benefits expected from policy reforms that would enhance efficiency and growth, such as trade liberalization and fiscal adjustment. In this situation the government will be circumspect on incurring more costs if it presumes that the future gains in terms of higher output will accrue mainly to foreign lenders.

In this research, we looked into the analysis of external debt and its effect on the economic growth of Niger

\section{STATEMENT OF THE PROBLEM}

In recent times, there has been increase concern about the external debt crisis of Nigeria. The country has acquired substantial amounts of external debt during this period. This poses serious problem to the nation's developmental needs. As stated by the Budget Office, the country's debt servicing burden reached critical proportions as reflected in the high amount of debt service and repayment as contained in the 2017 Nigeria Federal Budget where over 24\% of the annual budget is used for debt payment and servicing [3]. The external debt during the early 1980s increased Nigeria's official debt from US $\$ 4.1$ billion at end of 1980 to US $\$ 24.6$ billion by the end of 1986 . This was due to the nosedive in the world oil price which brought government expenditure above government earnings. The government had to borrow to finance its industrial projects. In 1999, Nigeria had an outstanding foreign debt of US $\$ 28.4$ billion, debt service payments amounted to US\$1.72 billion and payment arrears of US\$19 billion. Foreign debt stock stood at US\$32.92 billion at the end of December, 2003 while external debt service payment was about US $\$ 2.0$ billion during the same year.

As at the year 2000, Nigeria external debt profile was approximately $\$ 30$ billion, even though she has paid $200 \%$ on debt servicing alone over the principal sum borrowed. The debt crisis in Nigeria has constituted some hindrances to Economic Growth especially from 1980 till date. As a debt ridden country, Nigeria's economic growth is threatened as some macroeconomic variables such as unemployment, balance of payment, inflation, poverty, terms of trade, etc. are seriously affected. In 2005 , Nigeria's foreign debt profile received unparalleled attention, precisely on 29 June, 2005, Paris Club agreed to grant Nigeria a debt relief of US\$18.0bn from the $\$ 30.0 \mathrm{bn}$ owed. This came as a source of relief to the government and the people as the erratic and uneven debt demands and repayments can undermine the long-term development strategy of the nation. The external debt stock figure has continued to rise since 2005, in 2010 it was US\$4.6 billion, in 2014 it stood at US\$9.7 billion, in 2015 it was US $\$ 10.7$ billion, in 2016, US\$11.4 billion and in 2017 it was US\$18.9 billion.

Huge debt service obligations impose several constraints on a nation's growth prospect. It drains an economy's limited resources and hampers financial resources for the needed infrastructural development. Large debt servicing payments and debt burdens can restrain investment, and thus economic growth through its illiquidity and disincentive effects. Nigeria external debt has seriously affected key variables such as the External Debt (EXDT), External Debt Service (EXDS) and Exchange Rate (EXCHR).

\section{OBJECTIVES OF THE STUDY}

The major objective of this study is to evaluate the effect of external debts on the economic growth in Nigeria from $1980-2017$. While the specific objectives are:

i. To Determine The Effect Of External Debt On The Economic Growth Of Nigeria.

ii. To Investigate The Effect Of External Debt Service On The Economic Growth Of Nigeria

iii. To examine the effect of exchange rate on the economic growth of Nigeria

\subsection{Hypotheses}

The hypotheses outlined to guide the investigation are presented in null form as follows:

$\mathbf{H}_{\mathbf{0}}$ : External debt has no significant effect on economic growth.

Ho: External debt service has no significant effect on economic growth.

$\mathbf{H}_{\mathbf{0}}$ : Exchange rate has no significant effect on economic growth 


\section{LITERATURE REVIEW}

Odubuasi .A.C et. al., examined external debt and economic growth in Nigeria from 1980- 2013, they adopted Augmented Dickey Fuller (ADF) to test for the stationarity of the data, Granger Causality was used to obtain the cause effect relationship among variables while Error Correction Model was used to test the short and long run relationship. There finding indicates that external debt and government capital expenditure have positive and significant effect on economic growth in Nigeria while external debt service is not significant in explaining economic growth. [4].

Muhammad, .M.A et. al., examined the impact of external debt on growth and development of capital formation in Nigeria, they used Autoregressive Distributed Lag (ARDL) modelling on Time series data from 1980 to 2013. They noted that savings is an important component for capital formation and should be internally encouraged and given adequate priority in order to boost the speed of the growth of and development of capital formation in the Nigerian economy. [5]

Ijirshar .V. U et. al., examined the relationship between external debt and economic growth in Nigeria from 1981-2014. They employed descriptive and econometric tools in evaluating the time series data generated. The result shows a significant relationship between external debt and economic growth in Nigeria in a long run and on the other hand, external debt servicing had both long run and short run negative effect on Nigeria economic growth. They thus, recommended that external loan stock borrowed should be effectively managed since it increases growth rate. [6]

Udeh, .S.N et. al., researched on External debt and Economic growth: the Nigerian experience, from 1980 to 2013 , the variables used were Gross Domestic Product (GDP) as measurement for economic growth and dependent variable while, External Debt Stock, External Debt Service Payment and Exchange Rate were independent variables. The study used Ordinary Least Square for the analysis. Diagnostic tests were conducted using Augmented Dick Fuller Unit Root Test, Co-integration and Error Correction Model. The result showed that External Debt had a positive relationship with GDP at short run, but a negative relationship at long run. On the other hand, External Debt Service Payment had negative relationship with GDP, while Exchange Rate had a positive relationship with it. The conclusion was that exchange rate fluctuation had positive effect on the Nigerian economy while external debt stock and debt service payment had negative effect on the economy. The study recommendation includes amongst others, that the agency in charge of debt management in Nigeria ( Debt Management Office) should put in place mechanism that would ensure that foreign loans were utilized for purposes for which they were acquired and there should be a ceiling for borrowing for states and federal governments based on well-defined criteria.[7]

Mbah .S. A et. al., studied the impact of external debt on economic growth in Nigeria. Time series data were used and the data spanned from 1970 to 2013. The study employed ARDL bound testing approach, Johansen co-integration and error correction model of econometric were also used in analyzing the data. The finding of the Granger Causality indicates a unidirectional causality between debt and economic growth. Also, it shows that a long run relationships existed among the variables. In the same vein, external debt is found to have significant negative effect on GDP. They then concluded, that Nigeria has not benefited from the dividend accrued to external borrowing which is ought to bridge the savings- investment gap. [8]

James .A. A reviewed the interaction between external debt and economic growth, and analyses the sustainability of Nigeria's foreign debt. The study employed analytical method and the findings showed that debt relief would have positive impact on investment and growth. Furthermore, the work recommends that government needs to step-up its growth performance and use concessional debt with lower interest rate in order to keep the debt at sustainable level. [9]

Bamidele .T. B and Joseph .A. I investigated the effect of financial crisis, external debt management on the economic growth of Nigeria using GDP as endogenous variable while exogenous variables measuring economic growth were external debt, external reserve, Foreign Direct Investment (FDI), inflating, and exchange rate proxies. The study used time series data from 1980-2010. The ordinary Least Square (OLS), Augmented Dickey Fuller (ADF) unit roof tests and the Granger causality test were employed in analysis. The finding presented a positive relationship between FDI and economic growth while inverse relationship existed between external debt and economic growth [10]

According to Okonjo-Iweala .N the then Coordinating Minister for the Economy and Minister of Finance, she put the nation's external debt at $\$ 6.67$ billion, (about N1.035 trillion). Her words, "as at now, our external indebtedness is as low as $\$ 6.67$ billion or about 3 percent of Gross Domestic Product, GDP." The external debt is typically owed to foreign creditors such as multilateral agencies like the Africa Development Bank, World Bank, the Islamic Development Bank, as well as other bilateral source including the China Exim Bank, the French Development Bank or the Japanese Aid Agency, or to private creditors such as investors in our Eurobonds." Many of the multilateral loans are at zero interests, 40 years maturity, and 10 years moratorium. Other foreign loans are at less than 3 percent rate of interest. She emphasized that: we shall be vigilant on the position our national debt. We would be cautious on the amount of debt and put in limits to create room for the private sector instead of borrowing. Consequently, we would focus on continuous monitoring our external borrowing and ensure that we do not slip back to our high indebtedness prior 
to the debt relief programme. [11]

Ajayi .L.B and Oke .M.O worked on the impact of debt on investment and growth. It adopted regression analysis of OLS on secondary data sourced from CBN, Economical and Financial review, Business times, Financial Standard and relevant publication from Nigeria on variable like External Reserves, Debt Service Payment, National Income, Interest rate among others. The finding of the work indicates that external debt burden had an adverse effect on the nation income and per capital income of the nation. The study recommended that debt service obligation should not be allowed to rise more than foreign exchange earnings and that the loan contracted should be invested in profitable venture, that can generate a good amount of money for debt servicing and repayment.[12]

Ezeabasili, .V. N et. al., researched on the relationship between Nigeria's external debt and economic growth between1975-2006, with an error correction model. Error correction results revealed that external debt has negative relationship with economic growth in Nigeria. [13]

Furthermore, Adesola .W. A empirically investigated the effect of external debt service payment practices on the economic growth of Nigeria. OLS method of multiple regression was employed to evaluate how debt payment to multilateral financial creditors, Paris club creditors, London club creditors, Promissory Notes holders and other creditors relates to gross domestic product (GDP) and gross fixed capital formation (GFCF) applying data from 1981 to 2004. The work provides evidence that debt payment to Paris club creditors and Promissory Notes holders are positively related to GDP and GFCF while debt payment to London club creditors and other creditors show a negative significant relation to GDP and GFCF. [14]

Adepoju .A.A et. al., worked on the Effect of External Debt Management on Sustainable Economic Growth and Development: Lessons from Nigeria. The paper reviewed the roles of debt management practices on sustainable economic growth and development with particular emphasis on Nigeria. Information was generated extensively from literature, the Nigeria Central Bank and National Bureau of Statistic reports. It adopted regression analysis of OLS on secondary data. The analyses of the data collected with descriptive statistics shows that, availability of access to external finance strongly influences the economic development process of any nation. Their conclusion was that best arrangement in debt payment must be put in place from time to time in response to changes in the economy and the polity. Debt can be productive and fruitful if it is well managed so that the rate of return is higher than the cost of debt servicing. [15]

Demchuck .O examined the non linear impact of external debt on economic growth, the Debt Cum-Growth model with the Investment model and econometrics analysis techniques of multiple regressions were used. His findings indicate that external debt exerts a positive change on GDP. [16]

Macro .A et . al ., examined the theory and empirical evidence of external debt sustainability. The debt overhang model was used. The result showed that debt sustainability is a determinant for poverty alleviation and economic growth. The study recommended debt thresholds to ease temporary liquidity constraint of servicing public debt. [17]

Nweke, C from the stand point of the latter, foreign loans are ostensibly for development purposes or to facilitate industrial progress, or for improving the quality and quantity of food production. The cardinal objective is to increase the standard of living of the generality of the people. The author agreed with the existing theories that external borrowing is to finance production and stimulate development but did not highlight how it has positively affected the lives of Nigeria in terms of democratic service delivery. [18]

\section{RESEARCH METHODOLOGY AND MODEL SPECIFICATION}

The research is designed to be totally an ex-post facto research and econometric technique of investigation on external debt and economic growth in Nigeria from 1980 to 2017. This is because it considers quantitative data for analysis. To achieve the apriori expectations, the research will adopt the multiple regression analysis method of estimation technique. The econometric models used in this study utilized two sets of variables, namely, dependent and independent or explanatory variables. The dependent variable represents the measures of economic growth that may be affected by the external debt. The measure of economic growth to be adopted in this study is the Real Gross Domestic Product (RGDP). The independent or explanatory variables are the external debt, debt service and exchange rate under investigation.

\section{MODEL SPECIFICATION}

Following Oke . M.O and Sulaiman, .L.A model specification who examined the impact of external debt on the level of economic growth and the volume of investment in Nigeria between 1980 and 2008, we therefore adopted the same growth model to specify the model for this study. The result of the analysis indicates that there exists a positive relationship between external debt, economic growth and Investment which was confirmed by coefficient of determination (R2) of about $79.8 \%$. Our model follows the same OLS regression analysis as applied by the authors above. [19] 
The model is therefore, specified as follows:

\section{Functional Specification}

$\mathrm{RGDP}=\mathrm{f}($ EXDT, EXDS,EXCHR ) Equation 1

\section{Transformed to econometric terms as}

$\mathrm{RGDP}=\beta_{0}+\beta_{1} \mathrm{EXDT}+\beta_{2} \mathrm{EXDS}++\beta_{3} \mathrm{EXCHR}+\mathrm{U}_{\mathrm{t}}$ Equation2

Where:

RGDP $=$ Real Gross Domestic Product (a proxy for economic growth)

EXDT $=$ External Debt

EXDS $=$ External Debt Service

$\mathrm{EXCHR}=$ Exchange Rate

$\mathrm{U}=$ Error term

$\beta_{0}$ is a constant parameter

$\beta_{1}, \beta_{2}, \beta_{3}$ are parameters to be estimated

From the model, Real Gross Domestic Product (RGDP) is the dependent variable. The independent variables in the model are external debt, debt service and exchange rate. These variables have the ability to affect the rate of growth in the Nigerian economy negatively or positively.

\section{Apriori expectation}

$\beta_{0}>0, \beta_{1}>0, \beta_{2}>$ or $<0, \beta_{3}>0$

\section{METHOD OF DATA COLLECTION AND SOURCES OF DATA}

The data for this study was obtained from the Central Bank of Nigeria Statistical Bulletin for 2000, 2010, 2013,2015 and 2017. Debt Management Office Annual Reports for 2010, 2012, 2014 2015, 2016 and 2017. Journals, Internet, Text books etc. So the study adopted secondary data as information on these variables are readily available.

\section{ESTIMATION PROCEDURE}

To access the effect of external debt in the Nigerian economy,, the study will adopted time series data for the period $1980-2017$. The ARDL regression method and descriptive analysis were employed to establish the relationship between the variables of the study. The Coefficient of Determination $\left(\mathrm{R}^{2}\right)$ was also used to determine the total variation of the dependent variables as a measure of goodness fit. Other dynamic properties of model specification adopted in the study are Unit Root Test, Co-integration and Error correction model.

\section{DATA PRESENTATION AND ANALYSIS OF REGRESSION RESULT}

The study examines the effect of External Debt on economic growth in Nigeria. Descriptive statistics and Trends analysis of variables used in the study was carried out using bar chart. Estimation of the effect of external debt on economic growth in Nigeria was also analyzed in this chapter using the ARDL bound test co-integration employing Stata 15.

\subsection{Descriptive Statistics and Trend Analysis of the Variables}

Table 1.1: Descriptive Statistics

\begin{tabular}{|l|l|l|l|l|l|}
\hline Variable & Obs & Mean & Std. Dev. & Min & Max \\
\hline RGDP & 38 & 140627.4 & 169983.1 & 15789 & 568499 \\
\hline EXDT & 38 & 25047.89 & 8636.22 & 8938 & 39898 \\
\hline EXDS & 38 & 2257.79 & 1655.70 & 495.65 & 8807.16 \\
\hline
\end{tabular}


International Journal of Advances in Scientific Research and Engineering (ijasre), Vol 5 (11), November-2019

Source: Researcher's Computation using Stata 15, 2019

\begin{tabular}{|l|l|l|l|l|l|}
\hline EXCHR & 38 & 85.318 & 89.956 & 0.55 & 324 \\
\hline
\end{tabular}

Table 1.1 above shows that the mean of Real Gross Domestic Product, External Debt, Debt Service and Exchange Rate were 140627.4, 25047.89, 2257.79 and 85.31 respectively. Given this we can conclude that the average gross domestic product, were high between 1984 and 2014. The minimum, maximum and standard deviation values of the variables were also shown in the table.

Trend Analysis of the Time Series Data on RGDP, EXDT, EXDS and EXCHR.

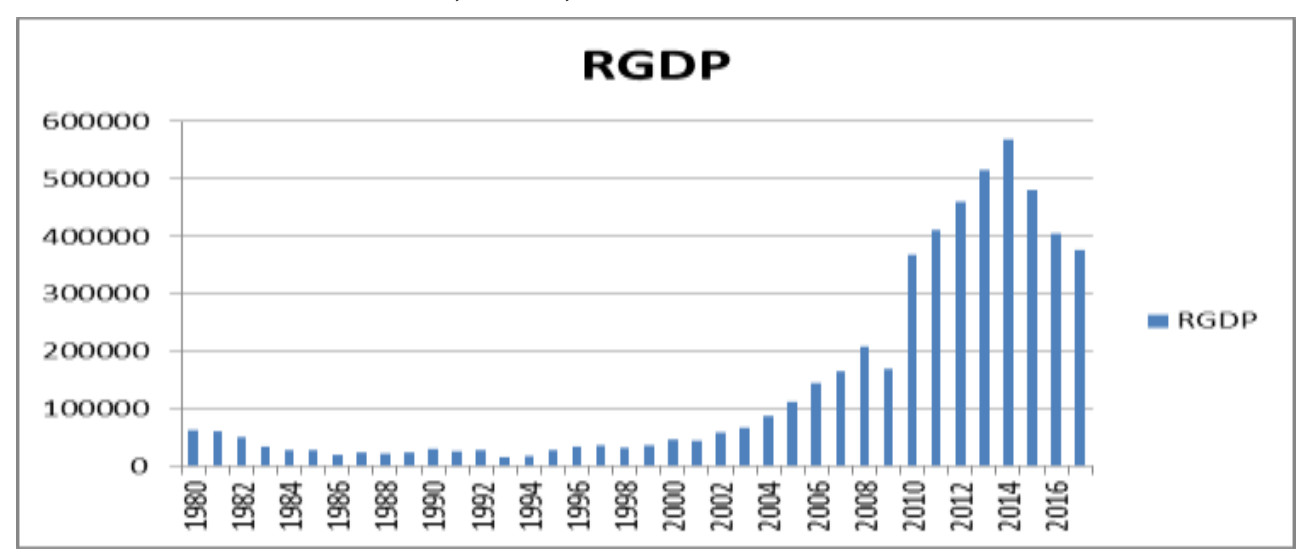

Figure 1.1: Line graph of RGDP

Source: Researcher's Computation using Excel,2019

Figure 1.1 above shows the trend of GDP over the period of study 1980-2017. GDP was lowest in 1994, recorded a considerable growth between 2002 and 2014 and declined sharply in 2015 up to 2017.

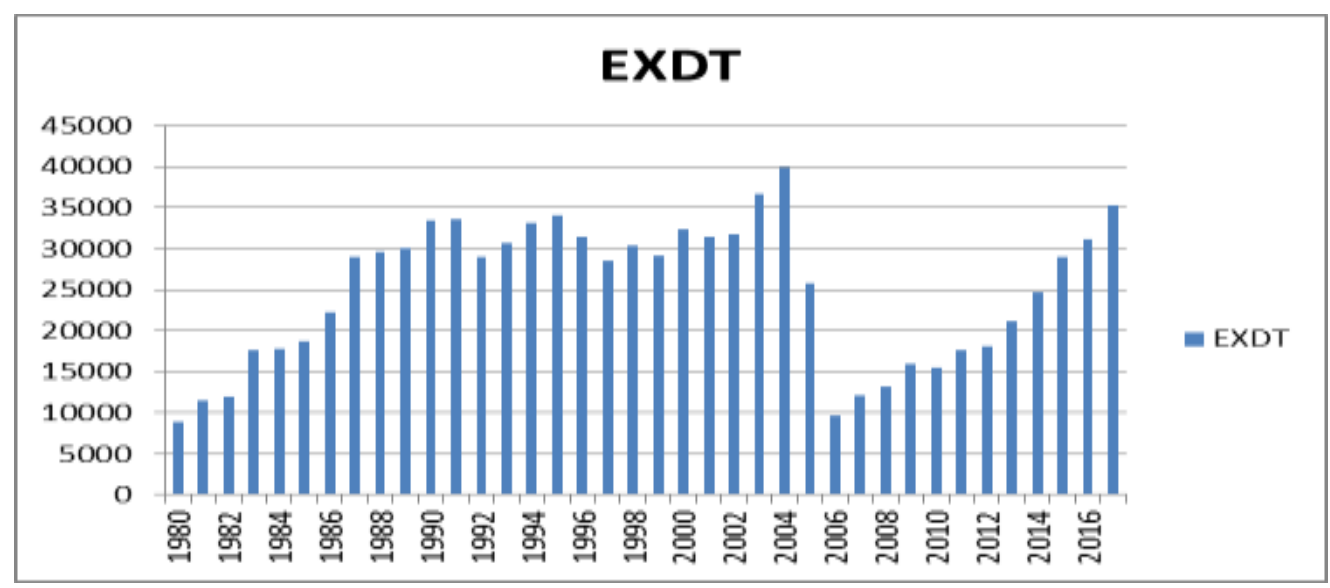

Figure 1.2: Line graph of EXDT

Source: Researcher's Computation using Excel,2019

Figure 1.2 above shows the trend of external debt over the period of study 1980-2017. EXDT fluctuated all through the period of study.

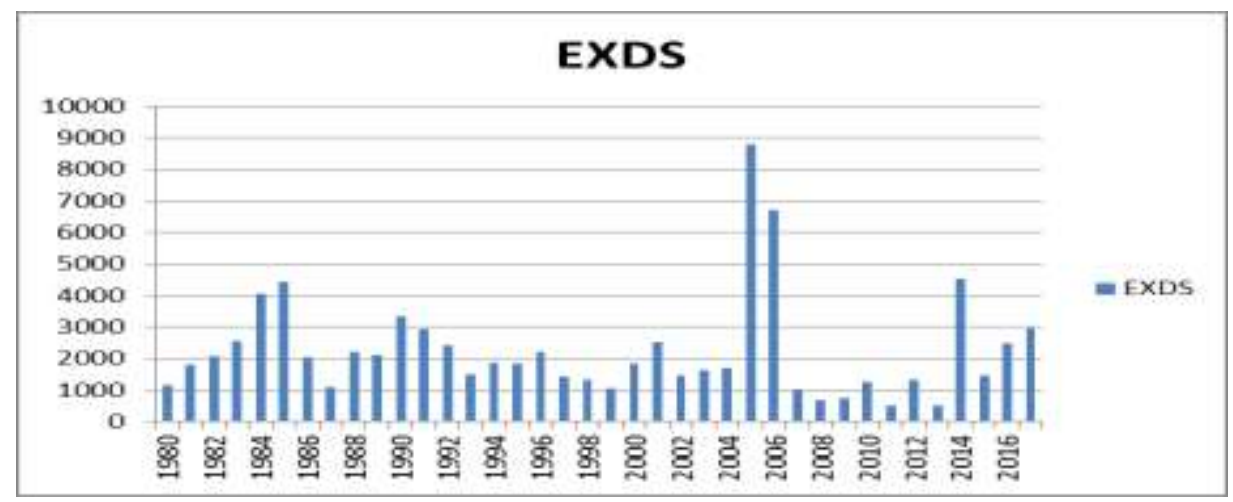


Figure 1.3: Line graph of EXDS

Source: Researcher's Computation using Excel,2019

Figure 1.3 above shows the trend of Debt Service over the period of study 1980-2017. EXDS was lowest in 2011 and highest in 2006. It recorded a considerable growth between 2015 and 2017.

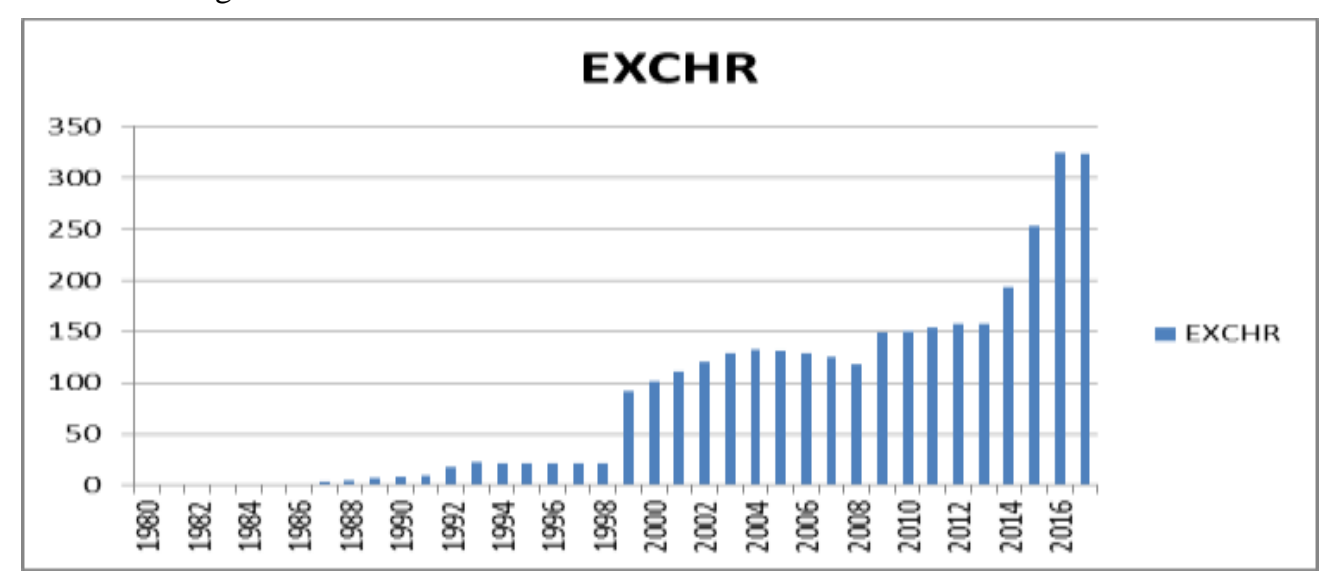

Figure 1.4: Line graph of EXCHR

Source: Researcher's Computation using Excel,2019

Figure 1.4 above shows the trend of exchange rate over the period of study 1980-2017. EXCHR was stable between 1980 and 1988 and rose sharply in 1999 getting to the peak in 2016.

\section{PRESENTATION OF UNIT ROOT RESULTS}

The Augmented Dickey Fuller (ADF) and Phillip-Perron unit root test were employed to test for stationarity of all the macroeconomic variables employed for the study. The results are presented on the table below

Table 1.2: Unit Root Test Result using Augmented Dickey Fuller (ADF)

\begin{tabular}{|l|l|l|l|l|l|}
\hline Variable & P-value@ level & $\begin{array}{l}\text { t-statistic @ first } \\
\text { difference(5\%) }\end{array}$ & $\begin{array}{l}\text { Pvalue@ 1 } \\
\text { Difference }\end{array}$ & $\begin{array}{l}\text { Critical } \\
\text { value(5\%) }\end{array}$ & $\begin{array}{l}\text { Order of } \\
\text { Integration }\end{array}$ \\
\hline RGDP & 0.1723 & -3.260 & 0.0168 & -2.972 & $\mathrm{I}(1)$ \\
\hline EXDT & 0.3610 & -3.984 & 0.0015 & -2.972 & $\mathrm{I}(1)$ \\
\hline EXDS & 0.0426 & -4.881 & 0.0000 & -2.972 & $\mathrm{I}(0)$ \\
\hline EXCHR & 0.8490 & -5.213 & & & \\
\hline
\end{tabular}

Source: Extract from computer on regression of data using Stata version 15,2019

Table 1.3: Unit Root Test Result using Phillips-Perron Unitroot Test

\begin{tabular}{|c|c|c|c|c|c|}
\hline Variable & P-value@level & $\begin{array}{l}\text { t-statistic @first } \\
\text { difference }(5 \%)\end{array}$ & $\begin{array}{l}\text { P-value @ } 1^{\text {st }} \\
\text { Difference }\end{array}$ & Critical value(5\%) & $\begin{array}{l}\text { Order of } \\
\text { Integration }\end{array}$ \\
\hline RGDP & 0.2790 & -5.309 & 0.0000 & -2.969 & $\mathrm{I}(1)$ \\
\hline EXDT & 0.3509 & -4.890 & 0.0000 & -2.969 & $\mathrm{I}(1)$ \\
\hline EXDS & 0.0020 & -8.410 & 0.0000 & -2.969 & $\mathrm{I}(0)$ \\
\hline EXCHR & 0.8894 & -5.213 & 0.0000 & -2.969 & $1(1)$ \\
\hline
\end{tabular}

Source: Extract from computer on regression of data using Stata version 15,2019

The decision rule here is that when the t-statistics is greater than the critical value at 5\% significance level and the probability value (P-Value) is less than 0.05 , it shows that the variable is stationary at level otherwise the difference is taken until it becomes stationary. The results show that all the variables tested were not stationary at level except EXDS. They became stationary only at first difference. The t-statistic values of the variables with the exception of EXDS were all greater than the critical values at the 
standard 5\% significant level and their probability values were greater than 0,05 at levels. The fact that the variables were not all stationary at level however connotes the existence of unit root and indication for co-integration. Therefore in order to avoid the misinterpretation bias that comes with analyzing co-integrated variables using the Ordinary least square estimation technique, the study tested for co-integration using the ARDL co-integration bound test. Sequel to the mix in the result of the unit root tests presented in tables 1.2 and 1.3 above, this study carries out the co-integration test using the Auto-Regressive Distributed Lag (ARDL) Bound Co-integration test.

Pesaran .M. H et. al., provide two asymptotic critical values (lower and upper) bounds for testing the existence of co-integration when the regressors are purely $\mathrm{I}(0)$ or $\mathrm{I}(1)$. A lower value assumes the regressors are purely $\mathrm{I}(0)$ while an upper value assumes the regressors are purely I(1). If the F-statistic falls outside the critical values, then a conclusive statement can be made regarding the nature of co-integration among the variables in the ARDL model, without a priori information on the order of integration of the independent variables. For instance, if the F-statistic is higher than the upper critical value, then the null hypothesis of no cointegration is rejected, suggesting the existence of co-integration among the variables. Conversely, if the F-statistic is lower than the lower critical value, then the null hypothesis of no co-integration cannot be rejected, suggesting the absence of co-integration among the variables. However, if the F-statistic falls between the upper and lower critical values, then the result is inconclusive. [20]

Table 1.4: ARDL Bound Co-Integration Test

\begin{tabular}{|l|l|l|}
\hline Estimated Model & F-Statistics \\
\hline & K_3 3.072 & Upper Bound I(1) \\
\hline Critical Values & Lower Bound I(0) & 5.61 \\
\hline $1 \%$ & 4.29 & 4.35 \\
\hline $5 \%$ & 3.23 & 3.77 \\
$10 \%$ & 2.72 & \multicolumn{2}{|l|}{} \\
\hline
\end{tabular}

Source: Authors' computation using Stata 152019.

From the co-integration result presented in table 1.4 above, it was observed that the value of the F-statistics for the estimating model which is 3.072 is lower than the lower bound critical value at five per cent, suggesting the absence of co-integration among the variables in the model, thus the study proceeded to estimate both the short and long run ARDL regression estimates.

\section{ANALYSIS OF ESTIMATES OF REAL GROSS DOMESTIC PRODUCT (RGDP) MODEL}

The ARDL regression estimates on both the long and short run relationship of the model for this study is presented on table 1.5 below. From the table it is observed that external debt (EXDT) is a significant determinant of real gross domestic product at 5\% level of significance and negatively related to it in the long run. External debt service (EXDS) is not a significant determinant of real gross domestic product at 5\% level of significance and negatively related to it in the long run. Exchange rate is a significant determinant of real gross domestic product at $5 \%$ level of significance and positively related to it in the long run. Specifically, the study observed

that a unit increase in EXDT and EXDS is expected to decrease the RGDP by 1.69 and 0.32 units respectively in the long run while a unit increase in exchange rate is expected increase the

RGDP by 0.69 unit in the long run. In the short run, from the table it was observed that EXDT is not a significant determinant of real gross domestic product at 5\% level of significance and positively related to it. EXDS is not a significant determinant of real gross domestic product at $5 \%$ level of significance and positively related to it. Exchange rate is not a significant determinant of real gross domestic product and negatively related to it.

Specifically, the study observed that a unit increase in EXDT and EXDS is expected to increase the RGDP by 0.09 and 0.11 units respectively while a unit increase in exchange rate is expected decrease the RGDP by 0.15 unit. From the adjusted estimate, the coefficient of the error correction term was correctly and negatively signed (-0.20) and statistically significant. The coefficient estimate of the error correction term of -0.20 implied that the model corrects its short-run disequilibrium by about 20 percent speed of adjustment in order to return to the long-run equilibrium. Furthermore, the coefficient of multiple determination of the model (R-squared) showed that the explanatory variables jointly explained about 97 per cent of the variations in the performance of the RGDP while the remaining 3\% per cent of the variations that is explained by variables not included in the model. The result of the coefficient of multiple determination showed that the model has a very good fit. Also, the result of the Durbin-Watson Stat of 2.13 showed that the estimate of the model is free from the problem of serial auto-correlation and that the model estimate is appropriate and can be used for policy recommendation. 
Table 1.5: ARDL Regression Estimates on RGDP Model.

\begin{tabular}{|l|l|l|l|l|}
\hline Variables & Coefficients & Std. Error & t-Statistics & Prob. \\
\hline ADJUSTED D.RGDP(ECM(-1) & $\mathbf{- 0 . 2 0 7 3}$ & $\mathbf{0 . 0 9 0 0}$ & $-\mathbf{2 . 3 0}$ & $\mathbf{0 . 0 3 0}$ \\
\hline LONG RUN ESTIMATE & -1.6908 & 0.6560 & -2.58 & 0.017 \\
\hline LEXDT & -0.3185 & 0.8004 & -0.40 & 0.694 \\
\hline LEXDS & 0.6788 & 0.1456 & 4.66 & 0.000 \\
\hline LEXCHR & \multicolumn{5}{l|}{} \\
\hline SHORT RUN ESTIMATE & 0.0913 & 0.3755 & 0.24 & 0.810 \\
\hline DLEXDT(-1) & 0.1080 & 0.1185 & 0.91 & 0.371 \\
\hline DLEXDS(-1) & -0.1460 & 0.1449 & -1.01 & 0.324 \\
\hline DLEXCHR(-1) & 5.935 & 2.5500 & 2.33 & 0.029 \\
\hline C & Adjusted R-Squared & 0.9611 \\
\hline R-squared & 0.9733 & Durbin-Watson Stat. & 2.138 \\
\hline F-Statistics (Prob.) $79.58(p<0.0000)$
\end{tabular}

Source: Author's Computation using STATA 15, 2019.

\section{EVALUATION OF HYPOTHESES}

At this point, it is pertinent to evaluate the research hypotheses which are guiding this research work. The hypotheses earlier stated are as follows;

$\mathrm{H}_{0}$ : External debt has no significant impact in stimulating economic growth in Nigeria

$\mathrm{H}_{0}$ : External debt service has no significant impact on economic growth in Nigeria

$\mathrm{H}_{0}$ : Exchange rate has no significant impact on economic growth in Nigeria

The Probability value of 0.810 for EXDT in the regression result which is greater than 0.05 at $5 \%$ significance level, indicated that EXDT is an insignificant determinant of RGDP. We therefore accept the null hypothesis and uphold that EXDT is not a significant determinant of RGDP. The Probability value of 0.324 for EXCHR in the regression result which is greater than 0.05 at 5\% significance level, indicated that EXCHR is not a significant determinant of RGDP. We therefore uphold the null hypothesis and state that EXCHR is not a significant determinant of RGDP. The result equally shows that EXDS is not a significant determinant of RGDP with P-value of 0.371 which is greater than 0.05 . We therefore uphold that DS is not a significant determinant of RGDP.

\section{SUMMARY OF FINDINGS}

In summary, the analysis of results from the study, shows that external debt has an insignificant but positive linear relationship with the level of economic growth in Nigeria. An increase in external debt by a unit will increased the level of economic growth by 0.091 units. This is an indication that external debt has the potentials of increasing the level of economic progress in Nigeria. External Debt service has no significant and positive impact on the level of economic growth in Nigeria. An increase in debt service by one unit will reduce the level of economic growth by 0.108 units. This is not surprising since income from investment of external debt in self-liquidating projects is used in servicing the debt. Exchange rate has no significant and positive impact on the level of economic growth in Nigeria.

\section{CONCLUSION}

Nigeria in recent time is faced with the challenges of infrastructural bottlenecks and capital inadequacy and therefore often end up borrowing repeatedly from foreign countries and international financial institutions. These have giving rise to huge total debt and high debt service obligations. Motivated by the increasing debt burden in the country, the study analyzed the effects of external debt on economic growth in Nigeria. Among the several findings of the study is that external debt and debt service insignificantly and positively impacted on investment and economic growth in Nigeria. The main recommendation from the findings of this study is that the country should invest external debts in self-liquidating projects that promotes investment and growth. Foreign loans should be applied on investment in infrastructures that promotes productivity and human capital development.

The study led to several findings and therefore several policy implications as well as recommendations are discussed below: 
i. The results show that external debt is a positive and insignificant determinant of RGDP in Nigeria. The study therefore recommends that economic managers in the country should apply foreign loans only on beneficial capital investments capable of liquidating itself rather than spend it on recurrent expenditure. This will reduce the crowding out effect of debt and debt overhang on the economy.

ii. Only external loans with favourable terms and conditions should be sort for by the country to avoid excessive debt burden on the economy. Proper tracking and monitoring of debt payment obligations should be embark upon.

iii. In the same light, the study recommends that only low cost loans, and concessionary loans with long moratorium shall be sort for after a rigorous evaluation not on exigency to reduce the cost of the debt. Also, a well-developed capital market will reduce the rate of external borrowing.

iv. Government should formulate and implement export oriented polices that would improve the country's export base as well as reduce its high level of deficit financing,

v. In addition to the above, other measures that will stabilize exchange rates in the country should be put in place to check its adverse effects on the economy.

\section{REFERENCES}

[1] Debt Management Office Nigeria, (2000), Annual Report and Statement of Account.

[2] Soludo, C.C. (2003). Debt Poverty and Inequality in Okonjo Iweala, Soludo, and Muhtar (Eds), The Debt Trap in Nigeria, Africa World Press NJ, pp. 23-74

[3] https://www.budgetoffice.gov.ng/index.php/2017-approved-budget

[4] Odubuasi .A.C., Uzoka. P.U. and Anichebe A.S (2018). "External Debt and Economic Growth in Nigeria". Journal of Accounting and Financial Management 4 (6) 98-108

[5] Muhammad, M.A., Hassan S.B and Abu Bakar N.A (2016). Analyzing the Impact of External Debt on Capital Formation in Nigeria: An Autoregressive Distributed Lag Approach https://www.mcser.org/journal/index.php/mjss/article/view/8658/8317

[6] Ijirshar V. U, Fefe, J, and Godoo M (2016). The Relationship between External Debt and Economic Growth in Nigeria. International Journal Economic Management Sci 6: 390

[7] Udeh, S.N., Ugwu, J.I., \&Onwuka, I.O. (2016). External debt and economic growth: The Nigeria experience. European Journal of Accounting, Auditing and Finance Research,4(2), $33-48$

[8] Mbah, S.A., Agu, O.C., and Umunna, G. (2016). Impact of external debt on economic growth in Nigeria: An ARDL bound testing approach Journal of Economics and Sustainable Development, 7 (10), 16-26

[9] James, A.A. (2014), The Debt Servicing Capacity of Nigeria's Economy.” University of Abuja: Department of Economics.

[10] Bamidele, T. B. \& Joseph, A. I (2013). Financial Crisis and External Debt Management in Nigeria, International Journal of Business and Behavioural Sciences, 3(4): 16 - 24.

[11] http://www.vanguardngr.com/2013/06/nigeria-owes-6-67-billion-external-debt-says-okonjo-iweala/\#sthash.4BmchSgl.dpuf

[12] Ajayi, L.B., and Oke, M.O. (2012), "Effect of External Debt on Economic Growth and Development of Nigeria.” International Journal of Business and Social Sciences. 3 (12): 10

[13] Ezeabasili, V. N., Isu, H. O. \& Mojekwu, J. N. (2011). Nigeria’s External Debt and Economic Growth: An Error correction Approach, International Journal of Busines and Management, 6(5) 1833 -8119.

[14] Adesola, W.A. (2009). Debt Servicing and Economic Growth in Nigeria: An Empirical Investigation, Global Journal of Social Sciences, 8 (2) 1-11.

[15] Adepoju, A.A, Salau. S., and Obayelu .E. (2007) The Effects of External Debt Management on Sustainable EconomicGrowth and Development: Lessons from Nigeria .( Department of Agricultural Economics and Extension Ladoke Akintola University of Technology Ogbomoso, Department of Agricultural Economics, University of Ibadan, Ibadan. Oyo State 
International Journal of Advances in Scientific Research and Engineering (ijasre), Vol 5 (11), November-2019 Nigeria)

[16] Demchuck O. (2003) Non-Linear Impact of External Debt on Economic Growth The Case of Post- Soviet countries, Master in Economics Thesis, National University of Kyiv-Mohyla Academy

[17] Macro, A., Luca, B. and Andrea, F.P. (2000). External Debt Sustainability: Theory and Empirical Evidence.” Virne Publishing Company. U.K. Birmingham

[18] Nweke, C (1990). The Origins and Dimension of Nigeria External debt: In Nigeria External Debt Crisis; Its Management. Edd by Adebayo O. Olukosi. Malthouse Press Ltd, $42-61$

[19] Oke, M.O., and Sulaiman, L.A. (2012). "External Debt, Economic Growth and Investment in Investment in Nigeria". European Journal of Business and Management. Vol.4(11):25-28

[20] Pesaran .M. H., Shin Y., and Smith, R.J (2001). Bounds testing approaches to the analysis Journal of Applied Econometrics, John Wiley \& Sons, Ltd., 16(3), 289-326.

of level relationships 